\title{
Identifying plant DNA in the faeces of a generalist insect pest to inform trap cropping strategy
}

\author{
Jerry Asalma Nboyine ${ }^{1,2} \cdot$ Stéphane Boyer ${ }^{3} \cdot$ David J. Saville $^{4} \cdot$ Stephen David Wratten $^{1}$
}

Accepted: 31 October 2019 / Published online: 10 December 2019

(C) INRA and Springer-Verlag France SAS, part of Springer Nature 2019

\begin{abstract}
Monocropping elevates many insects to the status of economic pests. In these agroecosystems, non-crop habitats are sometimes deployed as trap crops to reduce pest damage. This environmentally friendly alternative to pesticides can be particularly fitting when dealing with native invaders that may be afforded legal protection or enjoy public sympathy as is the case for the ground wêtā Hemiandrus sp. 'promontorius' (Orthoptera) in New Zealand. However, this approach requires knowledge of the insects' diet to select the most appropriate plant species for trap cropping. Here, ingested plant DNA in the faeces of wêtā was analysed to help develop strategies for mitigating its damage in New Zealand vineyards. DNA was extracted from faeces of wêtā collected from six different vineyards over four seasons. Using a DNA metabarcoding approach, we amplified the $r b c \mathrm{~L}$ gene region and sequenced the amplicons on an Illumina MiSeq platform. The identity of plants in the diet of this insect was determined by comparing the sequences generated with those available in the GenBank database and cross-checking the results with a database of plants known to be present in New Zealand. A total of 47 plant families and 79 genera were detected. Of the genera identified, Vitis, Poa, Festuca, Anthoxanthum, Anagallis, Camelina, Epilobium, Menyanthes, Pedicularis, Urtica, Garrya, Pinus and Tilia were the major ones (i.e. they were present in more than $50 \%$ of the faecal samples). The composition of the above plant taxa in faecal materials was significantly different between collection sites or dates, except for Menyanthes. The occurrence of the latter was significantly different between collection sites. These results indicate that effectively mitigating wêtā damage to vines requires the use of a diverse mix of plant species for trap cropping as wêtā seem to be highly generalist in their feeding behaviour even when plant diversity is relatively low.
\end{abstract}

Keywords Wētā $\cdot$ Diet analysis $\cdot$ DNA metabarcoding $\cdot$ Faeces $\cdot$ Pest management $\cdot r b c L$ Vineyards $\cdot$ New Zealand

\section{Introduction}

Agricultural intensification has led to monocultures of high yielding plant species/cultivars over vast areas of land. This provides abundant resources for insects feeding on those monocultural species, elevating them to the status of

Stéphane Boyer

stephane.boyer@univ-tours.fr

1 Bio-Protection Research Centre, Lincoln University, P. O. Box 85084, Christchurch 7647, New Zealand

2 CSIR-Savanna Agricultural Research Institute, P. O. Box 52, Tamale, Ghana

3 Institut de Recherche sur la Biologie de l'Insecte (IRBI)-UMR 7261 CNRS/Université de Tours, Parc Grandmont, 37200 Tours, France

4 Saville Statistical Consulting Limited, P. O. Box 69192, Lincoln 7640, New Zealand economic pests (Rusch et al. 2016). To reduce pest damage while maintaining a monocultural state, high amounts of inputs are often applied, especially prophylactic use of insecticides and herbicides. These practices have led to major biodiversity losses and unwanted adverse effects on arable land and the surrounding environment (Rockström et al. 2009). Although the risks to human health and the environment from these chemicals have resulted in some cases in shifts to more sustainable non-pesticide pest management practices (Ekström and Ekbom 2011), most food production worldwide still relies heavily on high-input practices.

Alternative strategies, although still under-deployed, have as a key component the enhancement of functional farmland plant diversity (Rusch et al. 2016). This is because areas of non-crop habitats in farmland can influence pest populations by harbouring pests' natural enemies (Gurr et al. 2016). Noncrop vegetation in or around farmland may also attract, divert or intercept the targeted insect pest(s) and reduce their damage 
to the main crop. These latter processes include trap cropping as well as supplemental management strategies such as trap vacuuming, trap harvesting, sticky traps and pesticide application to trap crops (Moreau and Isman 2012).

These pest management principles have been used worldwide in a variety of cropping systems including viticulture (e.g. Villanueva-Rey et al. 2014). For instance, although vineyards are almost monocultures, it is common for at least one grass species to cover the inter-row areas. In addition, strips of flowering plants (e.g. buckwheat, Fagopyrum esculentum Moench.) are sometimes sown under vines or in the inter-rows to enhance populations and fitness of natural enemies for managing important vine insect pests such as larvae of the leafroller complex (Epiphyas postvittana, Ctenopseustis spp., Planotortrix spp., etc.), leafhoppers (Erythroneura spp.) and other phytophagous insects (Shields et al. 2016). Inter-row vegetation and any surviving weeds could also act as alternative food sources for generalist insect pests, thereby potentially reducing economic damage.

However, successfully using this approach to manage pests hinges on identifying and deploying appropriate non-crop species (Gurr et al. 2016). Hence, deployment of a less suitable non-crop vegetation will not result in reduced pest damage to the main crop (Villa et al. 2016).

Generally, identification of candidate trap-crop species may involve the time-consuming observation of the insect's feeding behaviour, or alternatively, analysing its gut content or faeces for the most abundant plant species (Pompanon et al. 2012). Several classical methods of gut content or faecal analysis are available (e.g. microhistological analysis, near infrared reflectance spectroscopy, stable isotopes etc.), but they often lack taxonomic resolution (Soininen et al. 2009). More recently, advances in DNA barcoding, combined with highthroughput DNA sequencing, allow for the identification and characterisation of the composition of an animal's diet with much higher precision (Soininen et al. 2009; Alberdi et al. 2019; Pompanon et al. 2012; Boyer et al. 2013).

Insects emerge as pest when they are introduced to a new habitat, just as the introduction of new crop plants can also lead to novel associations where native species become pests (Lefort et al. 2015). This is the case for one species of wêtā which is native to New Zealand but has become a pest in vineyards (Nboyine et al. 2016). Wētā Hemiandrus sp. 'promontorius' are present in New Zealand's vineyards throughout the year and cause significant damage to vines at the specific period of budburst when they feed on the very young leaves (Nboyine et al. 2017).

Wētā are a well-known and iconic group of New Zealand insects comprising about 70 species in the families Anostostomatidae and Rhaphidophoridae. Their name is derived from that of Wêtāpunga, the god of ugly things in the Māori mythology. As such, these insects are considered Taonga (i.e. treasure) and must be protected. All wētā are endemic to New Zealand and many of them are at risk of extinction because of the degradation of their natural habitat and the introduction of mammalian predators (in particular rats, mice and stoats). Because many species are threatened, wêtā have become useful indicators of environmental health and the focus of numerous conservation initiatives. They are also ideal candidates for citizen science and science outreach projects because they are easier to work with than most other insects, they can be relatively large and are very appealing to the public. As a consequence, wêtā are one of the only insect groups that is well recognised and highly valued by the general public.

Due to their endemic status, their significance in the Maori culture and the sympathy they generate from the public, it is not conceivable to control wêtā populations with insecticides and alternative methods.

The current work therefore aimed at analysing ingested plant DNA in the faeces of a generalist orthopteran pest, a ground wētā (Hemiandrus sp. 'promontorius': Orthoptera, Anostostomatidae), in New Zealand vineyards to help identify candidate plant families/genera for inclusion in its management strategy, for example, as potential trap plants. Using generic PCR primers, we anticipate to detect a range of plant taxa eaten by wêtā and to obtain a good coverage of the insect's plant-based diet. According to the existing literature (e.g. Johns et al. 2001), we hypothesise that wêtā feed not only on grass and vines but also on a number of plant species that may be less common in New Zealand vineyards. Seasonal variation in diet is expected as some of the targeted plants may only be available at certain periods of the year.

\section{Materials and methods}

\subsection{Wētā collection sites}

Six vineyard blocks located in three different vineyard locations were sampled in the Awatere Valley, Marlborough, New Zealand, at elevations ranging from 8 to $46 \mathrm{~m}$ asl; O-Block (Castle Cliffs, $-41.6103{ }^{\circ} \mathrm{S}, 174.1276^{\circ} \mathrm{E}$ ) was 4.61 ha; DBlock (Castle Cliffs, $-41.6075{ }^{\circ} \mathrm{S}, 174.1328^{\circ} \mathrm{E}$ ) was 37.88 ha; H-Block (Castle Cliffs, $-41.6131{ }^{\circ} \mathrm{S}, 174.1359$ ${ }^{\circ} \mathrm{E}$ ) was 2.98 ha; L-Block ( The Favourite, $-41.6198{ }^{\circ} \mathrm{S}$, $174.1071^{\circ} \mathrm{E}$ ) was 16.88 ha; N-Block (The Favourite, $41.6260^{\circ} \mathrm{S}, 174.1105^{\circ} \mathrm{E}$ ) was 44.41 ha and CR-Block (Caseys Road, $-41.6880{ }^{\circ} \mathrm{S}, 174.120^{\circ} \mathrm{E}$ ) was 11.98 ha. These vineyards were subjected to conventional management practices, with weeds, insect pests and diseases being controlled with pesticides. The inter-rows were densely sown with grass mixtures dominated by Lolium perenne L., Festuca arundinacea Schreb. and Poa pratensis L., while under-vine areas sometimes harboured a few sparsely growing dicotyledonous weeds and grasses. In spring, under-vine areas were 
sprayed with conventional herbicides to remove weeds and maintain the soil bare. Pine tree (Pinus L. spp.) hedges bounded at least one side of each sampled block.

\subsection{Sampling wētā from vineyards for faecal analysis}

Sampling was performed during the day while wētā are generally buried in individual galleries (Fig. 1). On random locations in the vineyard, the upper layer of soil was swiftly removed with a movement of the shovel to expose galleries inhabited by wētā and draw the insects out. Wētā mid-instar larvae were hand-collected as they came out of their galleries. Each of the six vineyard blocks were sampled over four seasons, namely in July 2014, October 2014, January 2015 and April 2015. Sampling on one vineyard block took about $2 \mathrm{~h}$ and all blocks were sampled within 4 days at each season to avoid any difference in food availability due to plant phenology. In each season, 60 individual insects (i.e. 10 from each of the six vineyard blocks) were collected and placed singly in a labelled plastic arena $(9 \mathrm{~cm}$ height $\times 15 \mathrm{~cm}$ width $\times 15 \mathrm{~cm}$ length) lined with a double layer of tissue paper. The arenas were stored at room temperature $\left(20^{\circ} \mathrm{C}\right)$ for $24 \mathrm{~h}$, after which the insects were released. Individual wêtā mostly produced one faecal pellet which was stuck to the tissue paper. Each pellet was carefully transferred into a labelled $60 \mathrm{~mm}$ diameter Petri dish (excluding the tissue) and stored at $-80^{\circ} \mathrm{C}$ pending DNA extraction.

\subsection{DNA extraction}

DNA was extracted from 72 faecal samples (i.e. three randomly selected pellets per site per season) using a Zymo Research Fecal DNA MicroPrep ${ }^{\mathrm{TM}}$ kit. The manufacturer's protocol was followed with slight modifications. To extract DNA from wētā faeces, $500-\mu 1$ lysis solutions were pipetted into 72

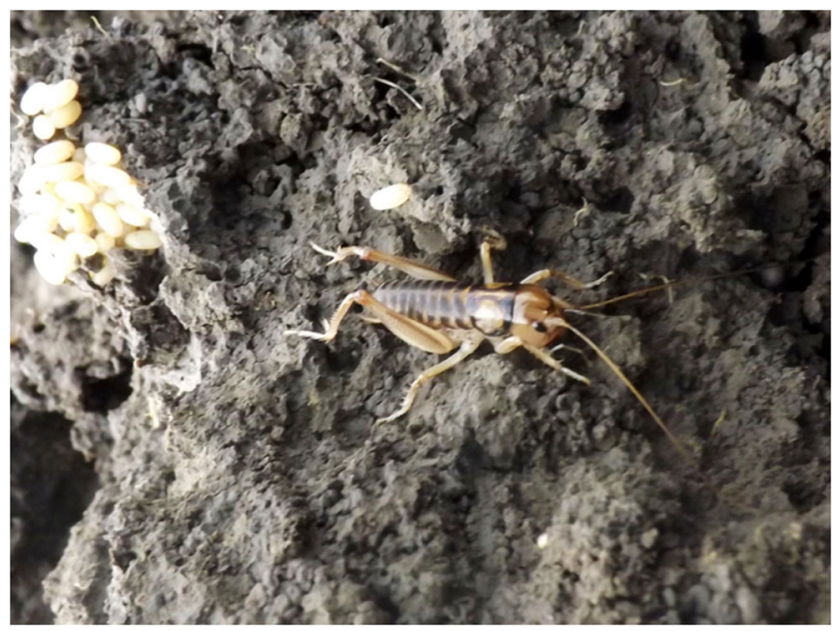

Fig. 1 Photograph of a female ground wētā Hemiandrus sp. 'promontorius' with egg clutch after excavation of her burrow individual BashingBead ${ }^{\mathrm{TM}}$ lysis tubes each containing faecal material. The DNA from the faecal material produced by an individual wētā was extracted individually as its weight was less than the $150 \mathrm{mg}$ recommended by the manufacturer. The tubes were secured in a bead beater and processed at 50 oscillations per second for $5 \mathrm{~min}$, followed by centrifuging at $10,000 \mathrm{~g}$ for $1 \mathrm{~min}$. The supernatants $(400 \mu \mathrm{l})$ were transferred to Zymo-Spin ${ }^{\mathrm{TM}}$ IV spin filters in collection tubes and centrifuged at 7,000 $\mathrm{g}$ for $1 \mathrm{~min}$. Faecal DNA binding buffer $(1200 \mu \mathrm{l})$ was then added to the filtrates after which the resulting mixtures were transferred to Zymo-Spin ${ }^{\mathrm{TM}} \mathrm{IC}$ columns in collection tubes and centrifuged at $10,000 \mathrm{~g}$ for $1 \mathrm{~min}$. This was followed by the addition of 200- $\mu$ l DNA pre-wash buffer and 500- $\mu$ l faecal DNA wash buffer to the columns and centrifuging for $1 \mathrm{~min}$ at $10,000 \mathrm{~g}$ after adding each reagent. The columns were transferred into clean $1.5-\mathrm{ml}$ microcentrifuge tubes and $30 \mu$ of DNA elution buffer were added directly to each column matrix. The tubes were centrifuged for $30 \mathrm{~s}$ at $10,000 \mathrm{~g}$ to elute the DNA. The latter was transferred into Zymo-Spin ${ }^{\mathrm{TM}} \mathrm{IV}-\mu \mathrm{HRC}$ spin filters in clean $1.5-\mathrm{ml}$ microcentrifuge tubes and left for $30 \mathrm{~min}$ before centrifuging at $8,000 \mathrm{~g}$ for $1 \mathrm{~min}$ for purification. The purified DNA was then amplified through polymerase chain reaction (PCR).

\subsection{PCR and electrophoresis}

The universal primer pair (rbcL19 and rbcLZ1 (Poinar et al. 1998)), which amplifies a $\geq 150$ base pairs (bp) fragment of the ribulose bisphosphate carboxylase large subunit (rbcL) chloroplast DNA gene region, was used to detect ingested plant DNA in wētà faeces. Primers were designed to include the recommended overhang adapters for Illumina sequencing. The PCR amplification was performed in $40-\mu 1$ reaction mixtures containing 6- $\mu \mathrm{l}$ DNA extract, $6.8-\mu \mathrm{l}$ water, $20-\mu \mathrm{l}$ GoTaq ${ }^{\circledR}$ Green $2 \times 2-\mu 1$ bovine serum albumin (BSA, $10 \mathrm{mg} / \mathrm{ml}), 2-\mu \mathrm{l} \mathrm{MgCl} 2(25 \mathrm{mM})$ and $1.6 \mu \mathrm{l}$ each of the forward and reverse primers $(10 \mu \mathrm{M})$. The protocol for the thermocycling was $94{ }^{\circ} \mathrm{C}$ for 5 min, 45 cycles of $94{ }^{\circ} \mathrm{C}$ for $30 \mathrm{~s}, 50^{\circ} \mathrm{C}$ for $30 \mathrm{~s}$ and $72^{\circ} \mathrm{C}$ for $30 \mathrm{~s}$, and a final elongation at $72{ }^{\circ} \mathrm{C}$ for $10 \mathrm{~min}$. Positive (Lolium perenne DNA) and negative (PCR grade water and wētā DNA extract) controls were included in each PCR to check for the success of amplification and DNA contamination, respectively. All PCR products underwent gel electrophoresis to check for successful amplification. Products of expected fragment size were cleaned with an Agencourt ${ }^{\circledR}$ AMPure $\AA$ XP PCR purification kit following the manufacturer's instructions and standardized at $2 \mathrm{ng} / \mu \mathrm{L}$. This procedure was also applied to the wêtā DNA negative control. Unique molecular identifiers (MID) were added to each of the 72 samples as well as the negative control before high-throughput DNA sequencing on one run of Illumina MiSeq using the $300 \times 300$ paired-end protocol as

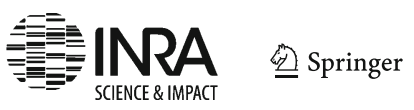


recommended by the manufacturer (https://support.illumina. com/downloads/16s_metagenomic_sequencing_library preparation.html). A 600 -cycle kit was used to sequence the amplicons on the MiSeq instrument. Read 1 was sequenced to 320 base pairs, and Read 2 sequenced to 280 base pairs. Identifier ligation and Illumina sequencing were performed by New Zealand Genomics Ltd, Auckland, New Zealand.

\subsection{Data analysis}

Paired-end reads were merged using the software VSEARCH version 1.9.5. For quality control reads were truncated at the first low-quality base (i.e. quality score $<3$ ) if present to ensure high-quality tails and accurate merging of the paired-end reads. Merged sequences from the Miseq run that were shorter than 150 bp were discarded because the expected length was $210 \mathrm{bp}$ ( $\sim 150 \mathrm{bp}$ for the internal amplicon plus $30 \mathrm{bp}$ for each primer). At this stage, we discarded any sequence with more than one expected error in the sequence as well as singletons (i.e. operational taxonomic units (OTUs) represented by a single read). To make the downstream analysis faster, nonunique sequences were then collapsed with a one base mismatch allowance. These unique sequences were clustered into molecular operational taxonomic units (MOTUs) using a conservative $97 \%$ identity threshold. Chimeric sequences were then removed using the UCHIME de novo method. To determine the identity of plant taxa in the diet of wêtā, each MOTU had its representative sequence searched against the GenBank nucleotide database using BLASTN version 3.2.31. Identifications accepted as correct matches and used for subsequent analyses in this study were those where BLAST search returned values of query coverage $>80 \%$ (i.e. identification based on at least 120 base pairs out of 150), and identity $>90 \%$ (i.e. identification at genus level). Because rbcL is not perfectly resolutive at the species level in plants and the DNA fragment used was very short, the risk of obtaining assignations that matched several different taxa with the same score was higher than that commonly encountered in DNA barcoding studies. To minimise the risk of multiple assignations, we conducted a barcoding gap analysis using the local minima function in the $\mathrm{R}$ package SPIDER (Brown et al. 2012) to determine the appropriate species identity threshold based on our own data. This analysis found the species identification threshold for our dataset to be $1.8 \%$ (Fig. 2). The accepted identifications were further cross-checked with a database of plants present in New Zealand (Allan Herbarium 2000). Sequences with no match in BLAST or with a match not recorded in the database of plants present in New Zealand were removed from the dataset and not used in subsequent analyses. See decision map in Fig. 2 for details.

Data were analysed as frequency of occurrence (FOO) and relative read abundance (RRA) (Deagle et al. 2019). To calculate FOO, the data were converted into presence (1)/absence
(0) before performing statistical analyses. To limit the potential inclusion of contaminants, a filtering step was also performed, in which 'presence' was assigned to MOTUs that occurred at least four times (i.e. 4 reads) in one faecal sample, while 'absence' was assigned to those that were detected less than four times and only present in one faecal sample.

Because our main interest was in the detection of food items that could potentially be used in a trap cropping strategy. Statistical analyses of FOO focused on major food items, which were defined as those genera which were detected in more than $50 \%$ of the faecal samples. These major taxa were Vitis sp. (vines), Poa spp. (grass), Festuca spp. (grass), Anthoxanthum spp. (grass), Anagallis spp. (weed), Camelina spp. (weed), Epilobium spp. (weed), Menyanthes spp. (weed), Pedicularis spp. (weed), Urtica spp. (weed), Garrya spp. (tree), Pinus spp. (tree) and Tilia spp. (tree).

Food items were categorised in two groups: 'cultivated' plants, when grown for economic reasons (vines) or to provide other beneficial services such as erosion control (grasses), and 'uncultivated' plants, which were weeds and trees growing inside or outside the vineyards, respectively.

Accumulation curves were built based on the cumulative number of plant families and genera detected in relation to the number of samples analysed using a bootstrap method to estimate diet coverage. Generalised linear models were used to determine the effect of sites and dates of sampling on the detection of each of the eight major taxa. The binomial distribution (with a binomial total of three faecal samples for each sampling unit) and logit link function were chosen for these analyses. The response variables were the diet (i.e. the eight major plant items), while the fitted model comprised date and site. Main effect means for either date or site that were significantly different were separated using least significant differences (LSD). Significant differences between the proportions of groups, subgroups and genera of plants were determined by computing the $95 \%$ confidence intervals (C. I.) of their mean. Relative read abundance was compared between sites and season using an analysis of deviance on a multivariate generalised linear model. A negative binomial distribution was chosen for this analysis based on the dispersion of the residuals. A $5 \%$ probability level was used for all tests.

\section{Results and discussion}

A total of 7,413,745 quality reads were obtained, of which $7,026,022$ reads provided quality matches with 540 MOTUs from GenBank. Applying a species identification threshold of $1.8 \%$ resulted in 40 MOTUs identified at species level and 500 that could only be identified at genus level. Of the latter, 366 MOTUs (i.e. 5,024,502 reads) corresponded to genera known to be present in New Zealand (Fig. 2). Overall, 80\% of plant taxa present in the faecal materials could be 
Fig. 2 Decision tree and number of reads and MOTUs retained or discarded at each step of the bioinformatics analysis

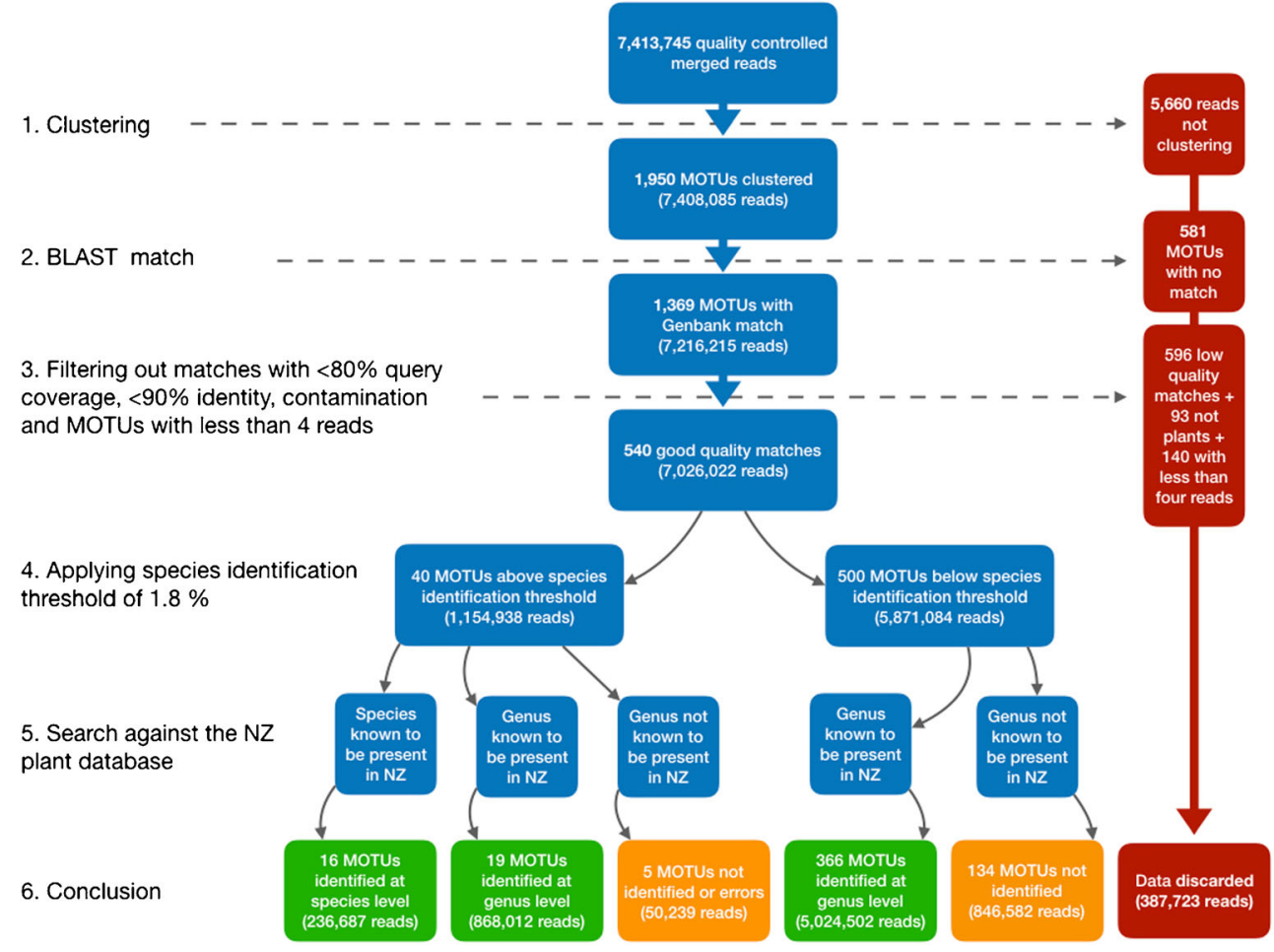

confidently identified at the genus level, while only $3 \%$ could be identified at species level. The $r b c \mathrm{~L}$ gene was therefore resolutive enough for genus level identification of plants, making it particularly suitable for studies focusing on ecosystems with moderate levels of plant biodiversity such as intensive agricultural landscapes. Based on these results, data was analysed only at the genus and family level and the following analyses were based on a total of 401 MOTUs represented by 6,129,201 reads (green boxes on Fig. 2).

In the current study, the $r b c \mathrm{~L}$ gene region was targeted using general primers. A major advantage of using a general primer set is that a priori knowledge of the range of potentially consumed species (i.e. taxonomic coverage) by herbivores is not required (Pompanon et al. 2012). In such single-locus studies, the P6 loop of the $t r n \mathrm{~L}$ intron or the $r b c \mathrm{~L}$ region are usually recommended because these regions are easily amplified and are well conserved in land plants, thus allowing to achieve a high taxonomic resolution when using a metabarcoding approach (Alberdi et al. 2019; Pompanon et al. 2012). In addition, these regions are relatively short (ranging between 12-134 bp and 150 bp respectively), which makes them more likely to be amplified from degraded DNA samples such as faeces and gut contents (Pompanon et al. 2012). In the New Zealand context, rbcL sequences are available for the great majority of native and naturalised plant genera (Lear et al. 2018), which makes it the better candidate. A recent study by McClenaghan et al. (2015) successfully described the diet of different species of grasshoppers (Orthoptera: Acrididae) in Ontario by using the same primers and identifying plants at the family level and to a lesser extent, at genus and species levels.

The identified taxa belonged to 47 plant families and 79 genera. According to a bootstrapped estimate using good quality sequences from 72 faecal samples, an estimated $93.7 \%$ of all plant genera and $96.4 \%$ of all plant families likely present in the diet of the wētā were successfully detected. Our analysis was therefore sufficient to determine the overall diet of that species at these taxonomic levels. Of the families detected, Poaceae comprised 12 genera, while the families Amaranthaceae, Asteraceae, Podocarpaceae and Rosaceae recorded four genera each. Except Lamiaceae, the remaining 41 families displayed at most two genera (Table 1). Overall (i.e. irrespective of sampling site or season) the genera Vitis, Poa, Festuca, Anthoxanthum and Tilia were more frequently detected than any other taxon (Fig. 3a).

The mean detection rate of cultivated plants (grasses and vines $)(P<0.05$; C. I. $=0.98-1)$ were significantly higher than that of uncultivated plants (weeds and trees) $(P<0.05$; C. I. $=$ $0.67-0.75)$. Pairwise comparisons of the mean proportional detections of the different categories of plants showed that vines and grass (Poa sp., Festuca spp., Anthoxanthum spp.) occurred more often than trees (Pinus spp., Tilia spp., Garrya spp., etc.) which were detected more often than dicotyledonous weeds (Anagallis spp., Camelina spp., Epilobium spp., Menyanthes spp., Pedicularis spp., Urtica spp., etc.) (Fig. $3 \mathrm{c})$. It is important to note that weeds were rare in the vineyards studied (J. Nboyine, pers. Observ.). However, every wētā collected had eaten at least one of these weed species in 
Table 1 Plant taxa identified from wētā faeces and their detection rate (i.e. proportion of wētā faecal material tested positive for each taxon)

\begin{tabular}{|c|c|c|c|}
\hline Family & Genera detected & Common name & Detection rate $(\%)$ \\
\hline Alstroemeriaceae & Luzuriaga Ruiz \& Pav. 1802 & - & 27.42 \\
\hline \multirow[t]{4}{*}{ Amaranthaceae } & Amaranthus L. & Amaranth & 24.19 \\
\hline & Atriplex L. & Saltbush & 9.68 \\
\hline & Chenopodiastrum (L.) S. Fuentes, Uotila \& Borsch & Nettle-leaved goosefoot & 3.23 \\
\hline & Suaeda Forssk. ex J. F. Gmel. & - & 35.48 \\
\hline Amaryllidaceae & Allium L. & Onion & 4.84 \\
\hline Apocynaceae & Catharanthus G. Don & Periwinkles & 8.06 \\
\hline \multirow[t]{2}{*}{ Asparagaceae } & Chlorophytum Ker Gawl. & Spider/airplane plant & 8.06 \\
\hline & Cordyline Comm. ex R.Br. & Cabbage-palm & 1.61 \\
\hline \multirow[t]{4}{*}{ Asteraceae } & Crepis L. & Narrowleaf hawksbeard & 3.23 \\
\hline & Guizotia Cass. 1829 & Annual herb & 8.06 \\
\hline & Senecio L. & Ragworts & 17.74 \\
\hline & Tragopogon $\mathrm{L}$. & - & 1.61 \\
\hline Betulaceae & Ostryopsis Decne. & - & 4.84 \\
\hline Boraginaceae & Cordia L. & Shrubby tree & 41.94 \\
\hline \multirow[t]{2}{*}{ Brassicaceae } & Camelina Crantz & False flax & 74.19 \\
\hline & Raphanus L. & Radish & 3.23 \\
\hline Calyceraceae & Acicarpha & - & 4.84 \\
\hline Cannabaceae & Celtis L. & Nettle trees/hackberries & 17.74 \\
\hline Caryophyllaceae & Silene L. & Catchfly & 3.23 \\
\hline Ceratophyllaceae & Ceratophyllum L. & Hornwort & 6.45 \\
\hline Convolvulaceae & Ipomoea $\mathrm{L}$. & - & 1.61 \\
\hline Cucurbitaceae & Cucumis L. & Muskmelon & 11.29 \\
\hline Cupressaceae & Cunninghamia R.Br. & - & 8.06 \\
\hline Cyperaceae & Carex $\mathrm{L}$. & Sedges & 1.61 \\
\hline Dennstaedtiaceae & Hypolepis Bernh. 1806 & - & 14.52 \\
\hline \multirow[t]{2}{*}{ Fabaceae } & Alysicarpus Desv. & Moneyworts & 1.61 \\
\hline & Lespedeza Michx. & Bush clovers & 1.61 \\
\hline Fagaceae & Quercus L. & Oak tree & 30.65 \\
\hline Garryaceae & Garrya Douglas ex Lindl. & Ashy silktassel & 87.10 \\
\hline Geraniaceae & Erodium Aiton & Redstem filaree & 12.90 \\
\hline Goodeniaceae & Scaevola L. & Fairy fun-flower & 1.61 \\
\hline Grossulariaceae & Ribes L. & Currants & 1.61 \\
\hline \multirow[t]{3}{*}{ Lamiaceae } & Nepeta L. & - & 22.58 \\
\hline & Prunella L. & Self-heal & 30.65 \\
\hline & Stachys L. & Woolly hedgenettle & 1.61 \\
\hline Lauraceae & Machilus Nees & - & 14.52 \\
\hline Malvaceae & Tilia $\mathrm{L}$. & Lime tree & 93.55 \\
\hline Menyanthaceae & Menyanthes L. & - & 70.97 \\
\hline Moraceae & Morus L. & Mulberry & 12.90 \\
\hline Myricaceae & Myrica L. & - & 12.90 \\
\hline Nothofagaceae & Nothofagus Blume & & 1.61 \\
\hline \multirow[t]{2}{*}{ Onagraceae } & Epilobium L. & Hoary willowherb & 53.23 \\
\hline & Oenothera L. & Tall evening primrose & 3.23 \\
\hline Orobanchaceae & Pedicularis L. & Warrior's plume & 72.58 \\
\hline \multirow[t]{2}{*}{ Pinaceae } & Cedrus Trew & - & 1.61 \\
\hline & Pinus L. & Pine & 67.74 \\
\hline \multirow[t]{2}{*}{ Poaceae } & Agrostis L. & Bentgrass & 43.55 \\
\hline & Anthoxanthum L. & Grass & 95.16 \\
\hline
\end{tabular}


Table 1 (continued)

\begin{tabular}{|c|c|c|c|}
\hline Family & Genera detected & Common name & Detection rate $(\%)$ \\
\hline & Dactylis L. & Grass & 4.84 \\
\hline & Eleusine (L.) Gaertn. & Goosegrass & 3.23 \\
\hline & Elymus L. & Grass & 27.42 \\
\hline & Festuca $\mathrm{L}$. & Fescue & 100 \\
\hline & Hordeum L. & Grass & 1.61 \\
\hline & Oryza L. & Rice & 3.23 \\
\hline & Paspalum L. & Crowngrasses & 48.39 \\
\hline & Poa L. & Grass & 98.39 \\
\hline & Sacciolepis Nash & Cupscale grass & 6.45 \\
\hline & Sporobolus R.Br. & Grass & 1.61 \\
\hline \multirow[t]{4}{*}{ Podocarpaceae } & Dacrydium Lamb. & - & 30.65 \\
\hline & Halocarpus C. J. Quinn & Tree & 1.61 \\
\hline & Nageia Gaertn, 1788 & Shrub & 4.84 \\
\hline & Podocarpus L'Hér ex Pers. 1807 & - & 4.84 \\
\hline \multirow[t]{2}{*}{ Polygonaceae } & Fagopyrum Mill. & Buckwheat & 14.52 \\
\hline & Polygonum L. & Japanese knotweed & 24.19 \\
\hline Primulaceae & Anagallis L. & Pimpernel & 59.68 \\
\hline Prumnopityaceae & Prumnopitys Phil. & - & 1.61 \\
\hline Ranunculaceae & Ranunculus L. & Buttercup/crowfoot & 3.23 \\
\hline Rhamnaceae & Ceanothus L. & - & 9.68 \\
\hline \multirow[t]{4}{*}{ Rosaceae } & Fragaria L. & Strawberries & 30.65 \\
\hline & Potentilla L. & Cinquefoils & 1.61 \\
\hline & Prunus L. & Bitter berry & 22.58 \\
\hline & Rubus L. & Raspberries, blackberries & 3.23 \\
\hline Salicaceae & Populus L. & - & 24.19 \\
\hline \multirow[t]{2}{*}{ Solanaceae } & Iochroma Benth. & Shrub & 20.97 \\
\hline & Solanum L. & Tomato & 19.35 \\
\hline Urticaceae & Urtica L. & Annual nettle & 69.35 \\
\hline Violaceae & Viola $\mathrm{L}$. & Crow-foot violet & 19.35 \\
\hline Vitaceae & Vitis L. & Grape vine & 100 \\
\hline
\end{tabular}

spite of the unlimited availability of grasses and vines. A similar pattern was observed for trees (Pinus spp., Tilia spp, Garrya spp., etc.), which were also represented in every faecal sample. The high diversity of plant families and genera identified from the faecal samples confirmed the status of this wētā as a generalist feeder. Species in the genus Hemiandrus are usually omnivores, feeding not only on a diverse range of plants including green leaves of trees and shrubs but also on other invertebrates (Van Wyngaarden 1995; Johns 2001). Diets comprising a mixture of plant and/or animal species are a common feeding behaviour among generalist orthopterans and other omnivore arthropods (Coll and Guershon 2002). This gives such insects a better nutrient balance than is possible by feeding on a single plant taxon, resulting in increased growth and survival (Coll and Guershon 2002; Berner et al. 2005). In addition, toxic secondary metabolites produced as defence mechanisms against herbivory by some plant species are diluted in mixed diets, reducing their effect on the insect (Ali and Agrawal 2012).

With regard to the relative abundance of reads (RRA), $45 \%$ of all reads belonged to Poaceae and $41 \%$ to vines leaving only $14 \%$ of reads to the 31 remaining families (Fig. 4). These percentages reflect the composition of plants communities generally observed in the studied vineyards. The interrows of the vineyards studied were dominated by grasses, which are low in protein content (below $50 \%$ of DM) and high in carbohydrates. As the grasses mature, protein content declines to less than $10 \%$ while carbohydrate increases (Lledó et al. 2015). Proteins are a major requirement of the diet of Hemiandrus spp. (Johns 2001). Being an omnivore, this insect could balance its protein intake by preying on other insects. The latter were however killed by the regular applications of insecticides in the vineyard. Therefore, sustainable intake of protein for this wētā appeared to rely on balanced feeding on 
a

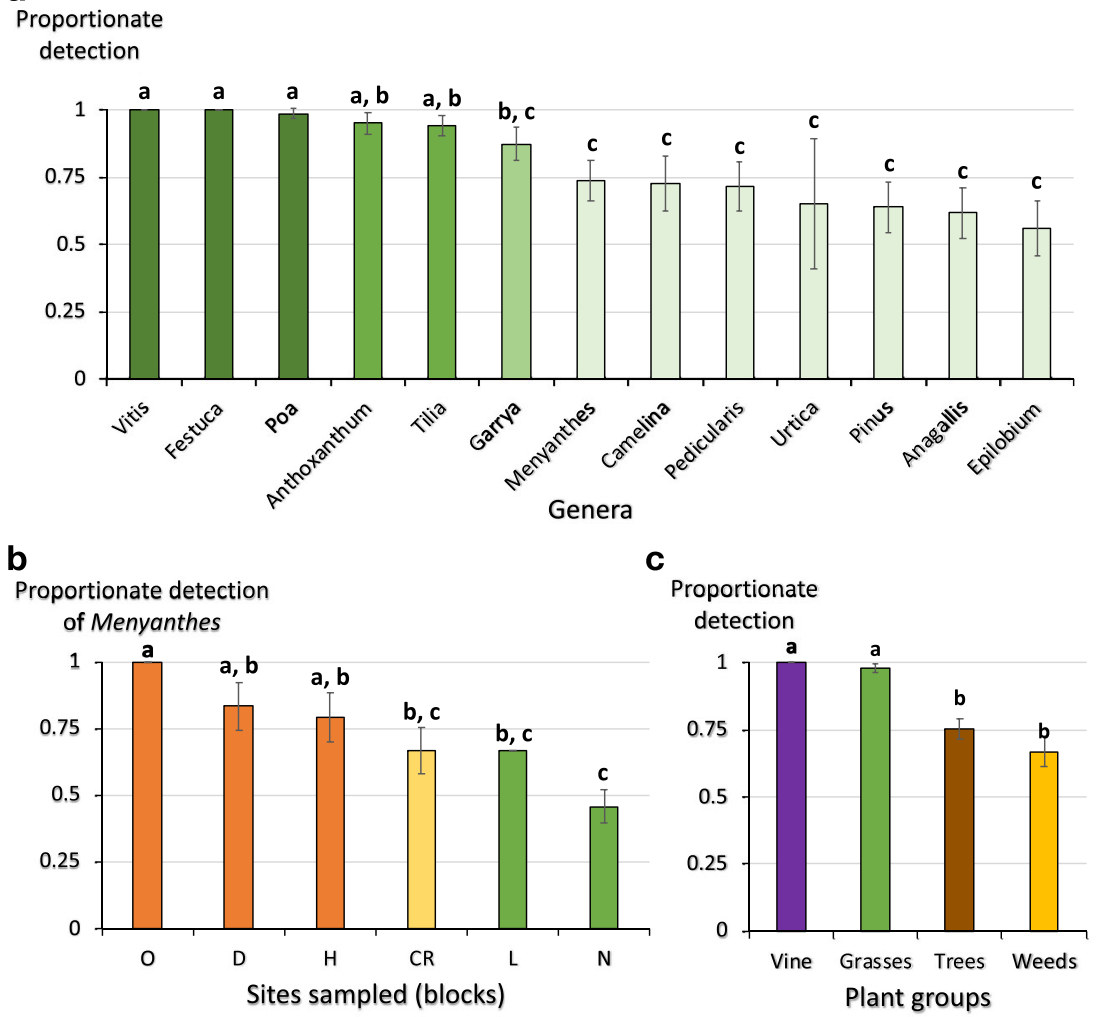

Fig. 3 Detection of plant DNA through molecular analysis of frass from wētā (Hemiandrus sp. 'promontorius'). a Proportion of the major plant genera detected. Data are means $\pm 95 \%$ confidence intervals. Bars with no letters in common are significantly different at the $5 \%$ probability threshold. b Proportion of wētā frass tested positive for Menyanthes spp. at different sites sampled. Data are means \pm standard error of means (S. E.). Bars with no letters in common are significantly different

weeds and tree species that have been detected, but because these were mostly rare in vineyards, it alternatively fed on vine buds. Hence, management practices that encourage patches of weed growth in vineyards could probably minimise wêtā feeding on vines.

No dietary variation was detected in relation to date of sampling based on FOO and RRA (LRT $=126.8, P=$ 0.262 ). This was true when analysing the full dataset and when focusing on the major food items (plant genera detected in more than $50 \%$ of the samples analysed). Indeed, the proportions of faecal samples that tested positive for DNA of Vitis, Poa, Festuca, Anthoxanthum, Anagallis, Camelina, Epilobium, Pedicularis, Urtica, Garrya, Pinus and Tilia did not change significantly with date. This result is possibly due to a limited number of samples analysed for each season as cumulative curves show that the 18 samples analysed per season allowed detection of an estimated $60.6 \%$ of all plant genera and $80.5 \%$ of all plant families in the diet of wêtā.

A significant difference was observed in relation to sampling location for RRA (LRT $=111.9, P=0.026$ ). In terms of detection, only Menyanthes, displayed a significant change in occurrence in relation to sampling location $(P=0.028)$. at the $5 \%$ level of significance. b Proportion of the different plant categories detected in wētā frass. Data are means $\pm 95 \%$ confidence intervals. Bars with no letters in common are significantly different at the $5 \%$ probability threshold. Trees: Pinus spp., Tilia spp. and Garrya spp.; weeds: Anagallis spp., Camelina spp., Epilobium spp., Menyanthes spp., Pedicularis spp. and Urtica spp.; grasses: Poa spp., Festuca sp. and Anthoxanthum sp.; vines: Vitis sp.

Detection of this flowering annual weed in wētā faeces was highest in the O-Block and lowest at the N-Block. The detection rate of this genus in the $\mathrm{D}-, \mathrm{H}-$ and $\mathrm{L}-$ Blocks was significantly lower than that recorded in the O-Block but higher than in the N-Block (Fig. 3b). These small geographical variations reflect slight differences in the blocks' plant communities and confirm that wētā are highly generalists and capable of feeding widely on the plants present in their environment.

Our study allowed for the identification of the main food items in the diet of wētā. This approach could be followed by food choice experiments to ascertain wētā food preferences between the small number of trap crop candidates identified here, and to select one or two optimal trap crops. Alternatively, and because wētā appear highly generalists, seeds of cultivars from various taxa could be sown in mixtures to provide divers alternative food for this insect. In this case, the main selection criteria may be the plant individual needs (climatic, soil, etc.) to ensure they provide enough resources at the critical time of vine budburst, thereby reducing damage to vines.

The deliberate use of weed species to attract natural enemies for insect pests' population regulation has been studied extensively (Sarkar et al. 2018). The findings here suggest that 


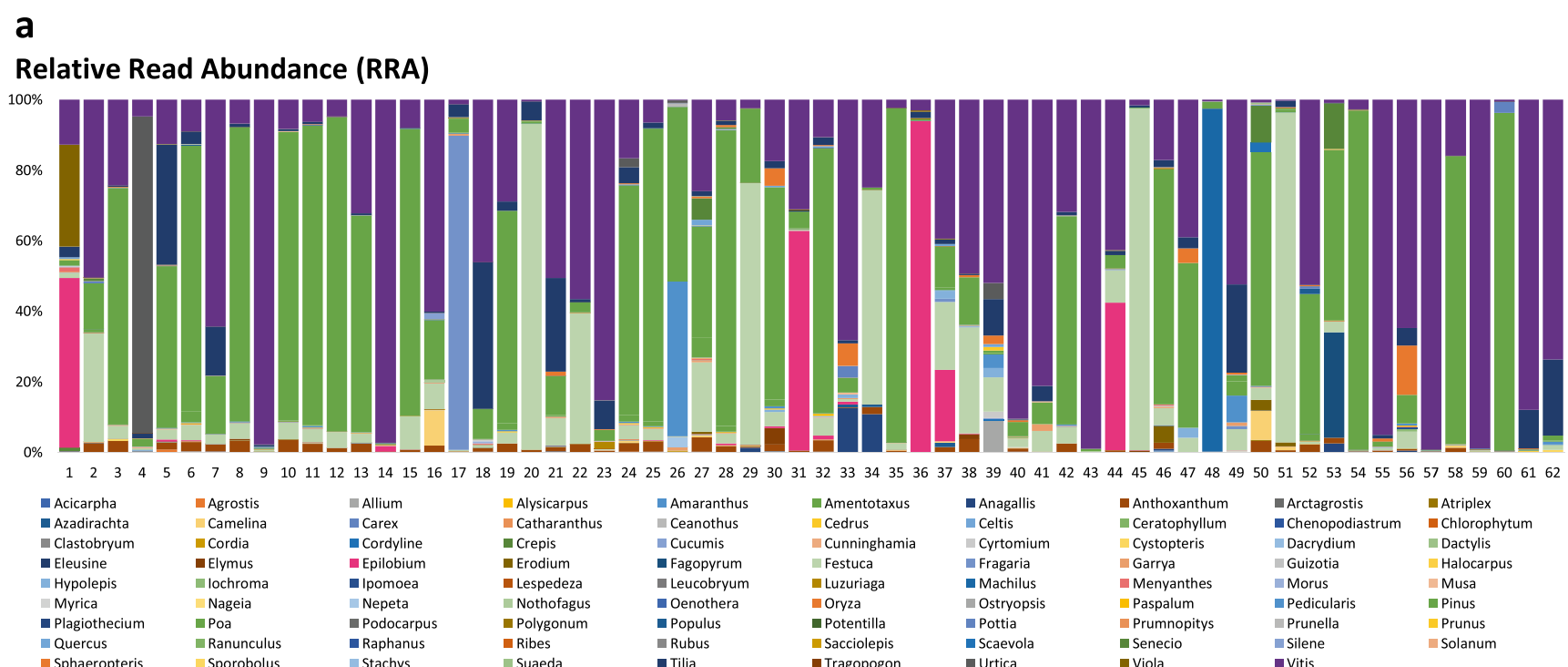

b

\section{Occurrence}

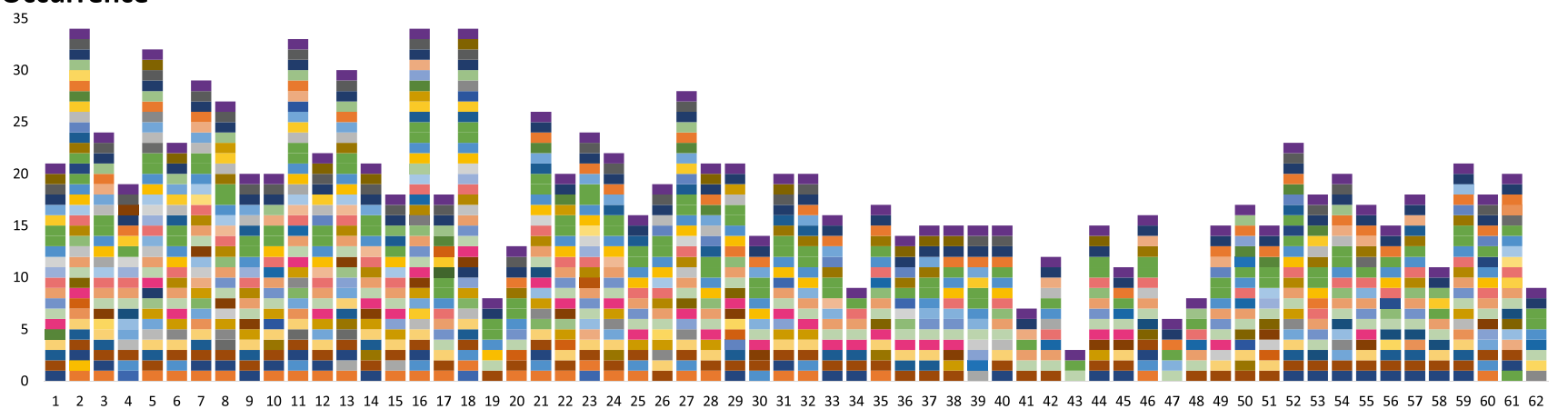

C

Frequency of occurrence (FOO)

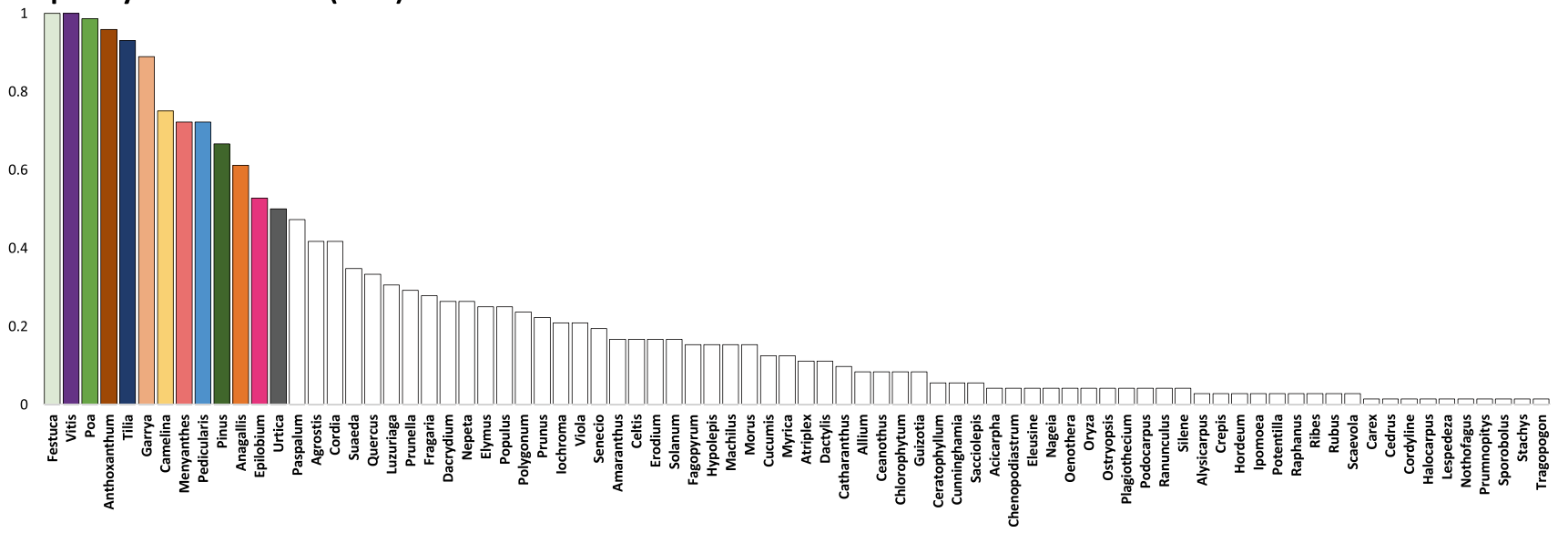

Fig. 4 Wētā individual diet analysis. Relative read abundance (a) and occurrence (b) of plant genera as measured from each individual faecal sample. Frequency of occurrence (c) of the different plant genera, with major food items represented in colour

this approach to pest management (when adopted by vine growers) would have the added advantage of reducing crop damage by generalist insect herbivores and omnivores such as wētā, which may use weeds as alternative foods. However, to limit the multiplication of wêtā, trap cropping should be restricted to the vine sensitive period (around budburst) and the trap crop removed as soon as the vine leaves are tough enough that they are no longer targeted by wētā. Some unexpected genera were detected in the faeces analysed. For example, Tilia spp. (an ornamental mostly found in urban parks and 
gardens), Populus spp., Solanum spp., Ipomoea spp., Cucumis spp., Quercus spp., etc. are not usually common around vineyards in New Zealand. Considering that the identified taxa were assigned up to the genus level, it is quite hard to anticipate the origin of those taxa in the samples analysed. Perhaps, they came from other sources. For example, because wêtā are omnivorous and known to also feed on other insects, the presence of tree DNA may be explained by secondary predation. Further studies would be needed to clarify this observation. This notwithstanding, the molecular diet analysis used here highlighted the high level of diet mixing in this species and hinted of potential plant families or genera that can be used for trap cropping. Based on these results, effective management of wētā will likely require sowing more than one plant species as trap crops to adequately satisfy the nutritional needs of this insect. The proposed method also presents some limitations. Firstly, the use of a short single-locus molecular marker only allowed identification of most plant MOTUs at the genus level and gives no information about predation on other invertebrates. This last point is important because prey nutrient content can modify omnivorous insect's propensity to engage in herbivory (Ugine et al. 2019). Secondly, the RRA may not be an accurate quantitative measure of actual amount of each species consumed (Deagle et al. 2019). Thirdly, there may be poor representations of particular species for which primer affinity was low (Alberdi et al. 2019). Nonetheless, this type of analysis provides extremely valuable information, and as NGS technology improves, some of the above limitations are becoming less problematic (see Alberdi et al. 2019; Pompanon et al. 2012).

\section{Conclusion}

In summary, the current work examined how the results of faecal DNA analyses could potentially contribute to developing trap cropping strategy for managing a generalist insect pest, thus reducing the high pesticide input in most modern agriculture. Primers targeting a short fragment of the $r b c \mathrm{~L}$ gene region were used to successfully identify the range of plants eaten by wētā, at least to the genus level. A wide variety of plant families were found in the diet of the target insect, in spite of grasses being abundant in vineyards. Such feeding behaviour is common among generalist insects, both herbivores and omnivores, and it is thought to ensure a balanced intake of major nutrients (proteins and carbohydrates). Hence, non-pesticidal management strategies for generalist insect pests could rely on trap crops that offset existing nutrient imbalances. For wētā, non-crop species with high protein content are recommended in agricultural systems dominated by plants with high carbohydrate content, and they should be planted to coincide with periods of damage to the economic crop. If these plants are potential weeds, they can be removed, for example with herbicides, once the main period of pest-induced damage has passed. The method used here could be applied to other agricultural pests, in particular, those feeding on seasonal resources. By collecting insects and analysing their diet outside their damaging period, it is possible to acquire the necessary knowledge to apply an efficient trap cropping strategy. Many non-crop plants in vines or other crops deliver a wide range of ecosystem services throughout the growing season (Shields et al. 2016), some of which are not well understood. Managing non-crop plants in agriculture is key to achieve 'sustainable intensification' and could be better informed through molecular diet analyses of pest species.

Acknowledgements The authors gratefully acknowledge Ollie Davidson, Joanne Brady, Craig Payne, Cliff Pilcher, Gerard Shand, Robert Blathwayt and the entire staff and management of Constellation Brands NZ for their support during the study. We are grateful to Dr Rob Cruickshank from Lincoln University for logistical support and access to his molecular laboratory. Staff in the Bio-Protection Research Centre, Lincoln University, are also gratefully acknowledged. We would like to thank two anonymous reviewers for their thoughtful suggestions that have considerably helped improving the manuscript.

Author contribution statement JAN, SB and SDW conceived and designed the research. JAN and SB conducted the research. JAN, DS and $\mathrm{SB}$ analysed the results. JAN and SB wrote the manuscript and prepared the figures. All authors read, contributed to and approved the final manuscript.

Funding information This study was funded by the New Zealand Government's Callaghan Innovations PhD Research and Development Grant, in partnership with Constellation Brands NZ (Project No. CONB1201). Other funding came from a Bio-Protection Research Centre grant and a Lincoln University fee scholarship.

Statement of data availability Data and analyses (R codes) are available on a Figshare repository (doi: 10.6084/m9.figshare.5777853).

\section{Compliance with ethical standards}

Conflict of interest The authors declare that they have no conflict of interest.

Ethical approval This article does not contain any study with animals performed by any of the authors.

\section{References}

Alberdi A, Aizpurua O, Bohmann K, Gopalakrishnan S, Lynggaard C et al (2019) Promises and pitfalls of using high-throughput sequencing for diet analysis. Mol Ecol Resour 19:327-348. https://doi.org/ 10.1111/1755-0998.12960

Ali JG, Agrawal AA (2012) Specialist versus generalist insect herbivores and plant defense. Trends Plant Sci 17:293-302. https://doi.org/10. 1016/j.tplants.2012.02.006

Allan Herbarium LR (2000) Ngā Tipu o Aotearoa-New Zealand plant names database. Landcare Research, New Zealand

Berner D, Blanckenhorn WU, Körner C (2005) Grasshoppers cope with low host plant quality by compensatory feeding and food selection: 
$\mathrm{N}$ limitation challenged. Oikos 111:525-533. https://doi.org/10. 1111/j.1600-0706.2005.14144.x

Boyer S, Wratten SD, Holyoake A, Abdelkrim J, Cruickshank RH (2013) Using next-generation sequencing to analyse the diet of a highly endangered land snail (Powelliphanta augusta) feeding on endemic earthworms. PLoS One 8:e75962. https://doi.org/10.1371/journal. pone.0075962

Brown SDJ, Collins RA, Boyer S, Lefort M-C, Malumbres-Olarte J, Vink CJ, Cruickshank RH (2012) Spider: an R package for the analysis of species identity and evolution, with particular reference to DNA barcoding. Mol Ecol Resour 12:562-565. https://doi.org/10.1111/j. 1755-0998.2011.03108.x

Coll M, Guershon M (2002) Omnivory in terrestrial arthropods: mixing plant and prey diets. Annu Rev Entomol 47:267-297. https://doi. org/10.1146/annurev.ento.47.091201.145209

Deagle BE, Thomas AC, McInnes JC, Clarke LJ, Vesterinen EJ et al (2019) Counting with DNA in metabarcoding studies: how should we convert sequence reads to dietary data? Mol Ecol 28:391-406 Available: https://onlinelibrary.wiley.com/doi/abs/10.1111/mec. 14734

Ekström G, Ekbom B (2011) Pest control in agro-ecosystems: an ecological approach. Crit Rev Plant Sci 30:74-94. https://doi.org/10.1080/ 07352689.2011 .554354

Gurr GM, Wratten SD, Landis DA, You M (2016) Habitat Management to Suppress Pest Populations: Progress and prospects. Ann Rev Entomol 62: 91-109

Johns P (2001) Distribution and conservation status of ground wētā, Hemiandrus species (Orthoptera: Anostostomatidae). Department of Conservation Wellington, New Zealand

Lear G, Dickie I, Banks J, Boyer S, Hannah L et al (2018) Methods for the extraction, storage, amplification and sequencing of DNA from environmental samples. N Z J Ecol 42:10-50S. https://doi.org/10. 20417/nzjecol.42.9

Lefort M-C, Worner SP, Rostas M, Vereijssen J, Boyer S (2015) Responding positively to plant defences, a candidate key trait for invasion success in the New Zealand grass grub Costelytra zealandica. N Z J Ecol 39:128-132

Lledó S, Rodrigo S, Poblaciones MJ, Santamaria O (2015) Biomass yield, mineral content, and nutritive value of Poa pratensis as affected by non-clavicipitaceous fungal endophytes. Mycol Prog 14:67. https://doi.org/10.1007/s11104-015-2596-0

McClenaghan B, Gibson JF, Shokralla S, Hajibabaei M (2015) Discrimination of grasshopper (Orthoptera:Acrididae) diet and niche overlap using next-generation sequencing of gut contents. Ecol Evol 5(15):3046-3055. https://doi.org/10.1002/ece3.1585

Moreau TL, Isman MB (2012) Combining reduced-risk products, trap crops and yellow sticky traps for greenhouse whitefly (Trialeurodes vaporariorum) management on sweet peppers (Capsicum annum). Crop Prot 34:42-46. https://doi.org/10.1016/j. cropro.2011.11.011

Nboyine J, Boyer S, Saville D, Smith M, Wratten S (2016) Ground wētā in vines of the Awatere Valley, Marlborough: biology, density and distribution. N Z J Zool 43:336-350
Nboyine JA, Boyer S, Saville DJ, Wratten SD (2017) Agroecological management of a soil-dwelling orthopteran pest in vineyards. Insect Sci. https://doi.org/10.1111/1744-7917.12425

Poinar HN, Hofreiter M, Spaulding WG, Martin PS, Stankiewicz BA, Bland H, Evershed RP, Possnert G, Pääbo S (1998) Molecular coproscopy: dung and diet of the extinct ground sloth Nothrotheriops shastensis. Science 281:402-406. https://doi.org/ 10.1126/science.281.5375.402

Pompanon F, Deagle BE, Symondson WO, Brown DS, Jarman SN, Taberlet $\mathrm{P}$ (2012) Who is eating what: diet assessment using next generation sequencing. Mol Ecol 21:1931-1950. https://doi.org/10. 1111/j.1365-294X.2011.05403.x

Rockström J, Steffen W, Noone K, Persson Å, Chapin FS III, Lambin E, Lenton T, Scheffer M, Folke C, Schellnhuber HJ (2009) Planetary boundaries: exploring the safe operating space for humanity. Ecol Soc 14

Rusch A, Chaplin-Kramer R, Gardiner MM, Hawro V, Holland J, Landis D, Thies C, Tscharntke T, Weisser WW, Winqvist C (2016) Agricultural landscape simplification reduces natural pest control: a quantitative synthesis. Agric Ecosyst Environ 221:198-204. https://doi.org/10.1016/j.agee.2016.01.039

Sarkar S, Wang E, Wu S, Lei Z (2018) Application of trap cropping as companion plants for the management of agricultural pests: a review. Insects 9(4):128

Shields MW, Tompkins J-M, Saville DJ, Meurk CD, Wratten S (2016) Potential ecosystem service delivery by endemic plants in New Zealand vineyards: successes and prospects. PeerJ 4:e2042. https:// doi.org/10.7717/peerj.2042

Soininen EM, Valentini A, Coissac E, Miquel C, Gielly L, Brochmann C, Brysting AK, Sønstebø JH, Ims RA, Yoccoz NG (2009) Analysing diet of small herbivores: the efficiency of DNA barcoding coupled with high-throughput pyrosequencing for deciphering the composition of complex plant mixtures. Front Zool 6:16. https://doi.org/10. 1186/1742-9994-6-16

Ugine TA, Krasnoff SB, Grebenok RJ, Behmer ST, Losey JE (2019) Prey nutrient content creates omnivores out of predators. Ecol Lett 22(2): 275-283

Van Wyngaarden, F (1995) The ecology of the Tekapo ground wêtā (Hemiandrus new sp., Orthoptera: Anostostomatidae) and recommendations for the conservation of a threatened close relative. Master of Science in Environmental Science, University of Canterbury, New Zealand. http://hdl.handle.net/10092/7752

Villa M, Santos SA, Mexia A, Bento A, Pereira JA (2016) Ground cover management affects parasitism of Prays oleae (Bernard). Biol Control 96:72-77. https://doi.org/10.1016/j.biocontrol.2016.01.012

Villanueva-Rey P, Vázquez-Rowe I, Moreira MT, Feijoo G (2014) Comparative life cycle assessment in the wine sector: biodynamic vs. conventional viticulture activities in NW Spain. J Clean Prod 65: 330-341. https://doi.org/10.1016/j.jclepro.2013.08.026

Publisher's note Springer Nature remains neutral with regard to jurisdictional claims in published maps and institutional affiliations. 